\title{
EFFECTIVENESS OF COGNITIVE ACADEMIC LANGUAGE LEARNING APPROACH MODEL IN CHINESE LANGUAGE LEARNING
}

\author{
P-ISSN: 2089-4341 | E-ISSN: 2655-9633 \\ https://uia.e-journal.id/akademika/article/view/940 \\ DOI: 10.34005/akademika.v9i02.940
}

Submitted: 2020-08-28 Reviewed: 2020-11-26 Published: 2020-11-30

\author{
Ariesa R. Binawati \\ restiantiariesa@gmail.com \\ Universitas Negeri \\ Surabaya
}

\author{
Bachtiar S. Bachri \\ bachtiarbachri@unesa.ac.id \\ Universitas Negeri \\ Surabaya
}

\author{
Fajar Arianto \\ fajararianto@unesa.ac.id \\ Universitas Negeri \\ Surabaya
}

\begin{abstract}
Pronunciations of Chinese that are different from Indonesian pronunciation make beginner learners feel difficult and the need for companions in learning Mandarin. Spelling mistakes make meaning mistakes in Chinese. This requires a language learning model. The Cognitive Academic Language Learning Approach(CALLA) model is a language learning model for the development of foreign language skills according to native speakers. So the CALLA model is used for learning Chinese in order to practice self-directed learning and Mandarin phonetics. This study aims to determine the effectiveness of the CALLA model in Chinese learning in 10th grade. The research method used was a quasiexperimental study in 10th grade with data collection in the form of a response questionnaire to assess learning independence and a performance assessment rubric to assess Mandarin phonetics and then analyzed by using the independent sample $t$-test. The results of $t$-test are $0.00<0.05$ in phonrtic aspect and $0.014<0.05$ in self-directed learning. This suggests that the Cognitive Academic Language Learning Approach Model is effectively used ini the 10th grade Mandarin learning in the phonetics and self-directed learning aspect.
\end{abstract}

Keywords: Cognitive Academic Language Learning Approach Models,

Mandarin, Phonetic, Self-Directed Learning

\begin{abstract}
Pelafalan bahasa Mandarin yang berbeda dengan pengucapan bahasa Indonesia membuat pembelajar pemula merasa kesulitan dan membutuhkan pendamping dalam belajar bahasa Mandarin. Kesalahan ejaan membuat kesalahan makna dalam bahasa Mandarin. Ini membutuhkan model pembelajaran bahasa. Model Cognitive Academic Language Learning Approach (CALLA) merupakan model pembelajaran bahasa untuk pengembangan keterampilan bahasa asing menurut penutur asli. Jadi model CALLA digunakan untuk belajar bahasa Mandarin untuk berlatih belajar mandiri dan fonetik Mandarin. Penelitian ini bertujuan untuk mengetahui keefektifan model CALLA dalam pembelajaran bahasa Mandarin di kelas XI. Metode penelitian yang digunakan adalah penelitian kuasi eksperimental kelas XI dengan pengumpulan data berupa angket respon untuk menilai kemandirian belajar dan rubrik penilaian kinerja untuk menilai fonetik Mandarin kemudian dianalisis dengan menggunakan uji
\end{abstract}


independent sample t-test. Hasil uji-t 0,00 $<0,05$ pada aspek fonrtik dan $0,014<0,05$ pada pembelajaran mandiri. Hal ini menunjukkan bahwa Model Pendekatan Pembelajaran Bahasa Kognitif Akademik efektif digunakan pada pembelajaran bahasa Mandarin kelas $X$ pada aspek pembelajaran fonetik dan mandiri.

Keywords: Cognitive Academic Language Learning Approach Models,

Mandarin, Phonetic, Self-Directed Learning

\section{INTRODUCTION}

Mandarin is needed as a foreign language that supports activities in this era. Chinese investors who invest a lot of their funds in Indonesia are the reason for the need to learn Mandarin. Mandarin learning exists in various educational institutions both formal and non-formal. High school is one of the formal education institutions that includes Mandarin as a specialization subject. Learning Mandarin in high schools includes comprehensive learning, namely listening, speaking, reading and writing. The speaking aspect is the most worrying aspect of speaking Mandarin. Mandarin and Asian languages have clear boundaries between words (Liu, Wu, Yang, \& Liu, 2011) and the ability to communicate orally is the biggest concern in the use and learning of Mandarin (Lan, 2014). The definition meant is that Mandarin is a tonal language and has differences in pronunciation. Indonesian also has a tone in the pronunciation of the phonemes, but the tone in Indonesian does not make a difference in the meaning or meaning of the word (Mulyaningsih, 2014). This difference in pronunciation often results in errors in pronunciation of Mandarin. If learning pronunciation is unaccompanied by novice learners, beginner learners will find it difficult to learn.

Learning Mandarin language requires learning strategies so that students can master Mandarin language skills. One of the language learning strategies is the CALLA (Cognitive Academic Language Learning Approach) learning model. The CALLA learning model has three strategies in it, namely cognitive, metacognitive and social strategies. The CALLA learning model with local wisdom is effectively applied in learning reading comprehension as evidenced by the observation that students have high motivation and are active in learning (Annisa \& Rinaldi, 2017). The CALLA learning model with metacognitive strategies has also been proven to be effective in learning to write English (Al-Jarrah, Mansor, Talafhah, Al-Jarrah, \& Al-Shorman, 2018). The CALLA learning model can facilitate language learning well from various strategies and train learners' self-directed learning towards language learning.

Learning Mandarin in Indonesia uses direct learning such as observation, repetition, and following learners (Mintowati, 2017). Direct learning that is widely used in learning Chinese by repeating the words of 
the learners and then imitating, learners are also hunted by learners to read quickly. This makes students not motivated to learn Mandarin on their own, the motivation that appears to be done immediately but will not get good results. Motivation is the main essence in creating learning independence (Chung, 2013). Direct learning in language learning also does not provide opportunities for learners to repeat language learning at home. As a result, the Mandarin language that is taught is less effective with students' lack of understanding in observing and reading texts (Adji, 2017). This is experienced by many beginner Mandarin learners so that Mandarin is only used as a foreign language learned in schools without any motivation to understand it deeply.

A learning model that is suitable for language learning is needed, not only providing foreign language learning but learning language to be understood and applied in real life. Pronunciations of Chinese that are different from pronunciation of Indonesian result in pronunciation errors for beginner learners. Direct learning in Chinese language learning does not lead to learning motivation so that the learning independence of Mandarin learners is lacking. Language learning strategies are needed in this case. One of the language learning strategies is the CALLA learning model. CALLA learning model in learning Mandarin to improve phonetic aspects and learners' learning independence. This study aims to determine the effectiveness of the CALLA learning model in Chinese learning on the phonetic aspects and the independent learning of class $X$ students.

\section{METHOD}

This study used a quasi-experimental design to determine phonetic improvement and the independence of learning Mandarin using the CALLA learning model. The research was conducted at one of the private high schools with two classes as the sample. The control class was carried out on class X IPA 3 students and the experimental class was carried out on class X IPS 3. The two classes had almost the same learner characteristics, namely enthusiasm for new learning and responsiveness in learning. The high school was chosen because it implements Mandarin as a specialization subject in class $X$ and has a large number of students. There are four classes that apply Mandarin as a specialization subject with a total of 154 students, the control class has 38 students and the experimental class has 39 students. The data to be collected is phonetic data obtained from the reading assessment of Chinese beginners and students' responses regarding self-directed learning Mandarin. The data collection technique used a questionnaire and assessment rubric. Questionnaires are used to collect students' responses about self-directed learning. The assessment rubric is used to collect beginner reading assessments through the reading performance test of Mandarin. The data were analyzed using the independent sample t-test to determine the significance of the effectiveness 
and improvement in the phonetic aspects and self-directed learning of learners in Mandarin.

\section{RESULTS}

The data obtained has been tested previously with the normality test and homogeneity test. The normality test is used to test the normality of the data distribution. Homogeneity test is used to test data equality. Phonetic data is normally distributed, self-directed learning data is also normally distributed. The two sample classes were tested for homogeneity through the report card value which stated that the two classes had equal or homogeneous abilities.

The results of the independent t-test obtained from the phonetic data of X IPA 3 and X IPS 3 are shown in Table 1. The table presents the results of the 2-sample comparative test, namely 0.00 with significant information because it is smaller than 0.05 and the difference of 2 means is obtained. minus value which indicates that there is an increase in phonetics in learning Mandarin using the CALLA learning model.

Table 1. Independent Sample T-Test for Phonetic Test Results

\begin{tabular}{lr}
\hline Probability Value (P Value) & 0,000 \\
\hline Significance & Significant \\
\hline Mean X IPA 3 & 15,447 \\
\hline Mean X IPS 3 & 17,692 \\
\hline Value Different Mean & $-2,245$ \\
\hline & Increase \\
\hline
\end{tabular}

The results of the independent t-test obtained from the independent learning data for X IPA 3 and X IPS 3 are shown in table 2. The table presents the results of the 2 sample comparative test, namely 0.014 with significant information because it is smaller than 0.05 and the difference of 2 means scores minus which indicates that there is an increase in self-directed learning in learning Mandarin using the CALLA learning model.

Table 2. Independent Sample T-Test for Self-Directed Learning Test Results

\begin{tabular}{lr}
\hline Probability Value (P Value) & 0,014 \\
\hline Significance & Significant \\
\hline Mean X IPA 3 & 35,132 \\
\hline Mean X IPS 3 & 36,590 \\
\hline Value Different Mean & $-1,458$ \\
\hline
\end{tabular}




\section{DISCUSSION}

The results of the independent sample t-test stated that the probability value or difference test was 0,000 , which was significant if the probability value was less than 0.05 (Hidayat, 2012), then $0,000<0.05$, meaning that there was a significant difference between X IPA 3 and X IPS 3 with learning Mandarin using the CALLA learning model. There is a significant difference in the use of hypermedia-based Chinese modules to improve language mastery in the phonetic field as $\mathrm{H} 0$, whereas, there is no significant difference in the use of hypermedia-based Mandarin modules to improve language mastery in phonetics which is used as $\mathrm{Ha}$. Then the hypothesis $\mathrm{HO}$ which states that there is a significant increase in the phonetic aspect using the CALLA learning model in Mandarin learning is accepted because the probability value ( $p$ value) is less than 0.05 and Ha which states that there is no significant increase in the phonetic aspect using the CALLA learning model in learning Mandarin is rejected. The results of the mean difference obtained from the independent sample t-test obtained a value of -2.245 which indicates an increase in phonetics using the CALLA learning model, namely X IPS 3.The mean difference value tends to be negative, then there is an increase, but if the mean difference is positive it shows there is a decline (Hidayat, 2012).

Mandarin is a tonal language, it is important to have accuracy in pronouncing tones in real communication (Ming \& Bai, 2011). Problems occurring with the pronunciation of Mandarin often occur for beginner learners. The difference in pronunciation of Mandarin and Indonesian will result in mistakes in pronunciation. This is evidenced by research which says that these errors will also result in errors in meaning, because there are differences in the use of tones in Mandarin which are different from Indonesian (Mulyaningsih, 2014). Pronunciation is one of the elements needed in communicating Mandarin. Pronunciation is also related to phonetics. Phonetic learning in this study is supported by using the media in the use of the CALLA model. Media is one of the factors that can improve skills and knowledge. This is supported by research that reveals that the use of media can gain knowledge, skills and attitudes, provide real experiences, increase motivation, and strengthen student absorption (Usman, Asri, Saleh, \& Ernawati, 2018). Learning Chinese using the CALLA model is included in the learning media so that students can use the CALLA model with fun. Effective communication learning uses the CALLA model (Cahyaningati, 2012). It is proven that the CALLA model is effective in improving Mandarin learning in the phonetic aspect.

The results of the independent sample t-test state that the probability value or difference test is 0.014 , significant if the probability value is less than 0.05 (Hidayat, 2012), then $0.014<0.05$ means that there is a significant difference in the development of the CALLA learning model on X IPA 3 and $X$ IPS 3 to improve self-directed learning. Then the hypothesis which states 
that there is a significant increase in self-directed learning using the CALLA learning model in Mandarin learning is accepted because the probability value ( $p$ value) is less than 0.05 and Ha which states there is no significant increase in self-directed learning using the CALLA learning model in learning Mandarin is rejected. The results of the mean difference obtained from the independent sample t-test obtained a value of -1.458 which indicates an increase in self-directed learning in the use of the CALLA learning model. The mean difference value which tends to be negative means an increase, but if the mean difference value tends to be positive, it indicates a decrease (Hidayat, 2012).

Self-directed learning is self-motivation in achieving learning goals through self-readiness (Nasrodin, 2018). Self-directed learning is needed in learning Mandarin so that understanding in Mandarin learning can be deep. Self-directed learning is characterized by independent decision making, self-motivation, not easily discouraged, thoughts that lead to the achievement of learning objectives, self-control, and time management (Sofiah, Yudisthira and Ardiansyah: 2009, Rianawati: 2014). Self-directed learning in learning Mandarin in this study is shown by the use of the CALLA model. The stages in the CALLA model teach students to learn Chinese. The stages of the CALLA model used are cognitive strategies. Cognitive strategies consist of source search, grouping, note-taking, deduction, auditory representation, elanoration and inference (Tarigan, 2009). The application of the CALLA model is assisted by using a hypermedia-based module equipped with audio media by minimizing assistance in learning. The CALLA learning model can motivate students to take an active role in the teaching and learning process (Annisa \& Rinaldi, 2017). This statement is proven by the results of the independent sample t-test which shows a minus value in the mean difference which means an increase in selfdirected learning. Students are motivated in learning Mandarin using the CALLA learning model and play an active role in it because it uses stages that invite students to take an active role in learning by taking notes and doing practice. This CALLA learning model is also supported by the existence of a hypermedia-based learning module so that students can play an active role in it without learner assistance.

\section{CONCLUSION}

The CALLA learning model is significantly effective in learning Mandarin with phonetic aspects and self-directed learning in class $X$ high school students. The CALLA learning model which is supported by a hypermediabased learning module can invite students to take an active role in learning Mandarin in the phonetic aspect. The CALLA learning model can be used as a reference for reexamining Mandarin learning, especially the phonetic aspects and self-directed learning. 


\section{REFERENCES}

Adji, F. (2017). Chinese Reading Teaching Materials Model Based on Authentic Materials. Al-Turas Bulletin: Forum for History, Literature, Culture and Religion, pp. 287-301.

Al-Jarrah, T. M., Mansor, N., Talafhah, R. H., Al-Jarrah, J. M., \& Al-Shorman, F. M. (2018). The Effect of Using CALLA Model Instructions Based on Metacognitive Writing Module on 12TH Grade Students' Writing Achievement. International Journal of Current Research, 76773-76779.

Annisa, W., \& Rinaldi, R. (2017). Learning Reading Comprehension with the Cognitive Academic Language Learning Approach (CALLA) Strategy based on Local Wisdom. Dialectics: Journal of Language, Literature and Indonesian Language and Literature Education, 240-258.

Cahyaningati, D. T. (2012). THE Effectiveness of CALLA Models on Improving Enginering Students Communicative Competence. Educate.

Chung, I.-F. (2013). Are Learners Becoming More Autonomous? The Role of SelfAccess Center in EFL College Students' English Learning in Taiwan. Asia-Pacific Edu Res, - .

Hidayat, A. (11 November 2012). Tutorial on How to Test the Independent T Test with Excel. Retrieved July 19, 2020, from Statistikian: https://www.statistikian.com/2014/08/student-t-test-dengan-excel.html

Lan, Y.-J. (2014). Does Second Life Improve Mandarin Learning by Overseas Chinese Students? Language Learning \& Technology, 36-56.

Liu, Q., Wu, L., Yang, Z., \& Liu, Y. (2011). Domain Phrase Identification Using Atomic Word Formation in Chinese Text. Elsevier, 1254-1260.

Ming, Y., \& Bai, Z. (2011). A Mandarin E-Learning System Based on Speech Recognition and Evaluation. Computer Applications in Engineering Education, 651-660.

Mintowati, M. (2017). Learning Mandarin in Schools: Alternative Approaches and Methods. Mandarin Horizon Journal, 1-10.

Mulyaningsih, D. H. (2014). Comparison of Indonesian and Chinese Phonology. Bahtera: Journal of Language and Literature Education, 1-10.

Nasrodin. (2018). Improved Independence and Mathematics Learning Outcomes through Peer Tutor Learning Strategies for Class XI PK Muhammadiyah Delanggu Students Odd Semester Academic Year 2016/2017. Journal of Convergence Education, 69-78.

Rianawati. (2014). Implementation of Character Values in Islamic Religious Education Subjects (PAI). Pontianak: IAIN Pontianak Press.

Sofiah, L., Yudisthira, \& Ardiansyah, R. (2009). Class VII SMP / MTS Economic Evaluation and Study Guide Series. Jakarta: Grasindo.

Tarigan, H. G. (2009). Strategy for Language Teaching and Learning. Bandung: Space Printing. 
Usman, M., Asri, W. K., Saleh, N., \& Ernawati. (2018). The Effect of Audio Media on the Students' Listening Ability in German Language Education Study Program, Makassar State University. Indonesian Journal of Educational Studies, 171-179. 